\title{
Prostaglandin $D_{2}$ pathway upregulation: Relation to asthma severity, control, and $\mathrm{T}_{\mathrm{H}} 2$ inflammation
}

\author{
Merritt L. Fajt, MDa, Stacy L. Gelhaus, $\mathrm{PhD}^{\mathrm{b}}$, Bruce Freeman, $\mathrm{PhD}^{\mathrm{b}}$, Crystal E. Uvalle, BS $^{\mathrm{a}}$, \\ John B. Trudeau, BA ${ }^{\mathrm{a}}$, Fernando Holguin, MD, MPH ${ }^{\mathrm{a}}$, and Sally E. Wenzel, MD \\ ${ }^{a}$ Division of Pulmonary, Allergy and Critical Care Medicine, Department of Medicine, University of \\ Pittsburgh Asthma Institute at UPMC/University of Pittsburgh School of Medicine

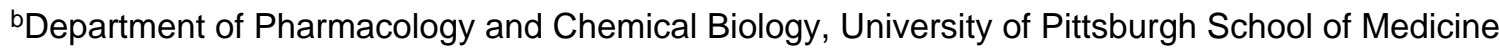

\section{Abstract}

\begin{abstract}
Background-Bronchoalveolar lavage (BAL) fluid prostaglandin $\mathrm{D}_{2}\left(\mathrm{PGD}_{2}\right)$ levels are increased in patients with severe, poorly controlled asthma in association with epithelial mast cells (MCs). PGD $_{2}$, which is generated by hematopoietic prostaglandin D synthase (HPGDS), acts on 3 $\mathrm{G}$ protein-coupled receptors, including chemoattractant receptor-homologous molecule expressed on $\mathrm{T}_{\mathrm{H}} 2$ lymphocytes (CRTH2) and $\mathrm{PGD}_{2}$ receptor 1 (DP1). However, much remains to be understood regarding the presence and activation of these pathway elements in asthmatic patients.
\end{abstract}

Objective-We sought to compare the expression and activation of $\mathrm{PGD}_{2}$ pathway elements in bronchoscopically obtained samples from healthy control subjects and asthmatic patients across a range of disease severity and control, as well as in relation to $\mathrm{T}_{\mathrm{H}} 2$ pathway elements.

Methods-Epithelial cells and BAL fluid were evaluated for HPGDS (quantitative real-time $\mathrm{PCR} /$ immunohistochemistry $[\mathrm{IHC}]$ ) and $\mathrm{PGD}_{2}$ (ELISA/liquid chromatography mass spectrometry) in relation to levels of MC proteases. Expression of the 2 inflammatory cell receptors DP1 and CRTH2 was evaluated on luminal cells. These $\mathrm{PGD}_{2}$ pathway markers were then compared with asthma severity, level of control, and markers of $\mathrm{T}_{\mathrm{H}} 2$ inflammation (blood eosinophils and fraction of exhaled nitric oxide).

Results-Confirming previous results, BAL fluid $\mathrm{PGD}_{2}$ levels were highest in patients with severe asthma (overall $P=.0001$ ). Epithelial cell compartment HPGDS mRNA and IHC values differed among groups ( $P=.008$ and $P<.0001$, respectively) and correlated with MC protease mRNA. CRTH 2 mRNA and IHC values were highest in patients with severe asthma $(P=.001$ and $P=.0001$, respectively). Asthma exacerbations, poor asthma control, and $\mathrm{T}_{\mathrm{H}} 2$ inflammatory markers were associated with higher $\mathrm{PGD}_{2}$, HPGDS, and CRTH2 levels.

Conclusion-The current study identifies coordinated upregulation of the $\mathrm{PGD}_{2}$ pathway in patients with severe, poorly controlled, $\mathrm{T}_{\mathrm{H}} 2$-high asthma despite corticosteroid use.

(c) 2013 American Academy of Allergy, Asthma \& Immunology

Corresponding author: Merritt L. Fajt, MD, Division of Pulmonary, Allergy and Critical Care Medicine, Department of Medicine, University of Pittsburgh Asthma Institute at UPMC/UPSOM, 3459 Fifth Ave, NW 628 Montefiore, Pittsburgh, PA 15213. fajtml@upmc.edu..

Disclosure of potential conflict of interest: M. L. Fajt has received grants from the National Institutes of Health (NIH). S. L. Gelhaus has received grants/has grants pending from the NIH. B. Freeman has received grants from the NIH; has received travel expenses from the NIH; has patents planned, pending, or issued by Complexa; has stock/stock options in Complexa and Nitromega. S. E. Wenzel has received consulting fees or honoraria from Actelion and Merck; has received payment for a Multicenter Study conducted for Array; has consultant arrangements with Amgen, Regeneron, and Novartis; and has grants/grants pending from Amgen, Genentech MedImmune, Sanofi Aventis, GlaxoSmithKline, and Merck. The rest of the authors declare that they have no relevant conflicts of interest. 


\section{Keywords}

Asthma control; chemoattractant receptor-homologous molecule expressed on $\mathrm{T}_{\mathrm{H}} 2$ lymphocytes; prostaglandin $\mathrm{D}_{2}$; severe asthma; $\mathrm{T}_{\mathrm{H}} 2$ inflammation

Although severe asthma remains poorly understood, ${ }^{1-3}$ many studies support mast cell (MC) involvement. ${ }^{4-6}$ Activated MCs generate lipid mediators, particularly cysteinyl leukotrienes and prostaglandin $\mathrm{D}_{2}\left(\mathrm{PGD}_{2}\right){ }^{7}$ with increased $\mathrm{PGD}_{2}$ levels recently reported in bronchoalveolar lavage (BAL) fluid from patients with severe asthma (SA), particularly in relation to frequent/severe exacerbations. ${ }^{6} \mathrm{PGD}_{2}$ is generated by prostaglandin $\mathrm{D}$ synthases after conversion of arachidonic acid to $\mathrm{PGG}_{2}$ and $\mathrm{PGH}_{2}$ by COXs. ${ }^{8}$ The lipocalin type is expressed in brain, cardiac, and adipose tissue, whereas hematopoietic prostaglandin $\mathrm{D}$ synthase (HPGDS) is mainly expressed in MCs, macrophages, dendritic cells, and $\mathrm{T}_{\mathrm{H}} 2$ cells. ${ }^{8-10}$ Studies in patients with nasal polyps, rhinosinusitis, and eosinophilic esophagitis suggest that MCs are the predominant source of HPGDS. ${ }^{11-13}$

$\mathrm{PGD}_{2}$ acts through the $3 \mathrm{G}$ protein-coupled receptors thromboxane receptor (TP), $\mathrm{PGD}_{2}$ receptor 1 (DP1), and chemoattractant receptor-homologous molecule expressed on $\mathrm{T}_{\mathrm{H}} 2$ lymphocytes (CRTH2/DP2), only 2 of which are found on inflammatory cells. ${ }^{9}{ }^{910}$ Binding $\mathrm{PGD}_{2}$ (and thromboxane) with high affinity, TP promotes smooth muscle constriction and platelet aggregation and likely contributes to allergen-induced bronchoconstriction. ${ }^{9,}, 10 \mathrm{In}$ contrast, DP1 activation causes vasodilation and bronchodilation in smooth muscle, inhibits platelet aggregation, and can promote polarization and recruitment of $\mathrm{T}_{\mathrm{H}} 2$ lymphocytes through inhibition of $\mathrm{T}_{\mathrm{H}} 1$ cytokines. ${ }^{14,15} \mathrm{CRTH} 2$ activation on $\mathrm{T}_{\mathrm{H}} 2$ lymphocytes, eosinophils, and basophils enhances chemotaxis and activation and potentially contributes to the development and maintenance of a $\mathrm{T}_{\mathrm{H}} 2$ immune process. ${ }^{9,10}$ Additionally, CRTH2 activation of $\mathrm{T}_{\mathrm{H}} 2$ cells induces cytokine production, which could promote IgE pathway activation on $\mathrm{MCs}$, further enhancing $\mathrm{PGD}_{2}$ generation.

On the basis of our previous findings of increased epithelial MC numbers and $\mathrm{PGD}_{2}$ levels in $\mathrm{SAs}^{6}$ and recent positive CRTH2 antagonist studies in asthmatic patients, ${ }^{16-18}$ we hypothesized that increased $\mathrm{PGD}_{2}$ levels would be accompanied by expression of its synthesizing enzyme, HPGDS, as well as upregulation of at least 1 of its receptors, CRTH2, on eosinophils and CD3 lymphocytes. This coordinated pathway upregulation would associate with poor asthma control, increased exacerbations, and a $\mathrm{T}_{\mathrm{H}} 2$ immune process. To address this, epithelial and BAL cells and fluid from asthmatic patients and healthy control subjects (HCs) were evaluated for $\mathrm{PGD}_{2}$ and HPGDS in relation to MC proteases, as well as DP1 and CRTH2 on luminal inflammatory cells. These $\mathrm{PGD}_{2}$ pathway markers were then compared with asthma severity, level of control, and $\mathrm{T}_{\mathrm{H}} 2$ inflammatory markers. Some results have previously been reported in abstracts. ${ }^{19-21}$

\section{RESULTS}

\section{Demographics}

Bronchoscopic samples were obtained from 112 subjects, and groups did not differ by race or sex (Table I). SAs were older (overall $P<.0001$, all intergroup $P<.0002$ ) and had a higher body mass index compared with HCs (intergroup $P<.0001$ ). Less atopy and lower serum IgE levels and blood eosinophil numbers were found in HCs compared with asthmatic patients. SAs had the lowest $\mathrm{FEV}_{1}$ percent predicted values, which were lower than in all other groups (overall $P<.0001$, all intergroup $P<.0001$ ). Leukotriene modifier use was more common in SAs compared with that seen in patients with milder asthma. Long-acting 
$\beta$-agonist use did not differ between SAs and the Mild-Mod/ICS group. Forty (87\%) SAs were using systemic corticosteroids.

All 112 subjects had BAL fluid $\mathrm{PGD}_{2}$ measurements. Because of the availability or quality of the samples, $89(80 \%)$ had epithelial cell brushing and 98 (87\%) had BAL cell mRNA data (see Table E1 in this article's Online Repository at www.jacionline.org). Immunohistochemistry (IHC) data were available in a subset ( $n=52$ [epithelial] and $n=47$ [BAL cell]). The subgroup with additional IHC data did not differ from those with mRNA and $\mathrm{PGD}_{2}$ data in any basic demographic characteristic, lung function, or medication use (see Table E2 in this article's Online Repository at www.jacionline.org). In total, 88 (79\%) had data from each of the 3 sample types (BAL fluid, BAL cells, and epithelial brushings; see Fig E1 and Table E3 in this article's Online Repository at www.jacionline.org for subanalysis based on the completeness of the parameters).

\section{Severe asthma is associated with evidence of $\mathrm{PGD}_{2}$ pathway activation}

We previously reported increased $\mathrm{PGD}_{2}$ levels in BAL fluid of SAs compared with that of HCs and patients with milder asthma, 33 of whom are included in the current analysis. ${ }^{6}$ The addition of 79 new subjects expanded and confirmed these prior findings because BAL fluid $\mathrm{PGD}_{2}$ concentrations differed among the groups (overall $P=.0001$ ) and differentiated SAs from HCs and the Mild-Mod/ICS group (Fig 1). Analysis of the 79 nonoverlapping subjects confirmed the findings of the larger cohort and validated the findings from the previous report by Balzar et $\mathrm{al}^{6}$ (overall $P=.0016$, see Fig E2 in this article's Online Repository at www.jacionline.org). Because BAL fluid $\mathrm{PGD}_{2}$ levels were generally low, LCMS confirmed $\mathrm{PGD}_{2}$ levels in 10 subjects and correlated with ELISA-determined levels $\left(r_{s}=\right.$ $0.80, P=.006$, see Fig E3 in this article's Online Repository at www.jacionline.org).

\section{The $\mathrm{PGD}_{2}$ synthesizing enzyme HPGDS is increased in the asthmatic epithelium}

mRNA-Epithelial cell brushing HPGDS mRNA levels differed among the groups (overall $P=.008$ ), were higher in SAs compared with HCs, and tended to be higher in the MildMod/ICS group compared with those seen in HCs (Fig 2, $A$ ). In all subjects epithelial cell brushing HPGDS and MC protease mRNA levels correlated $\left(r_{s}=0.75, P<.001\right.$ [tryptase]; $r_{s}=0.67, P<.001$ [CPA3]; Fig 2, $B$; see Table E4 in this article's Online Repository at www.jacionline.org for MC mRNA by subject groups). In SAs $(\mathrm{n}=35)$ the correlation of HPGDS with MC proteases was even stronger $\left(r_{s}=0.88, P<.0001\right.$ [tryptase]; $r_{s}=0.86, P$ $<.0001$ [CPA3]), suggesting a common epithelial MC source, whereas the correlation in HCs $(\mathrm{n}=26)$ was less strong $\left(r_{s}=0.48, P=.01\right.$ [tryptase]; $r_{s}=0.32, P=.11$ [CPA3]). HPGDS mRNA levels in the epithelium did not correlate with BAL fluid $\mathrm{PGD}_{2}$ levels, even when evaluated based on severity.

IHC/protein-Epithelial brushing HPGDS staining differed across groups (total $\mathrm{n}=52$, overall $P<.0001)$. The percentage of $\mathrm{HPGDS}^{+}$cells was highest in SAs and differentiated SAs from both the milder asthma group and the HCs (all intergroup $P \leq .0004$; Fig $3, A$ ). Staining in SAs suggested that positive cells included MCs (Fig 3, B). Epithelial cells themselves did not stain for HPGDS. HPGDS ${ }^{+}$cell numbers and mRNA levels modestly correlated $\left(\mathrm{n}=48, r_{s}=0.38, P=.008\right)$. Similar to HPGDS mRNA levels, $\mathrm{HPGDS}^{+}$cell numbers correlated with MC protease mRNA levels $\left(r_{s}=0.40, P=.004\right.$ [tryptase]; $r_{s}=$ $0.45, P=.001$ [CPA3] $)$ and also correlated with BAL fluid $\mathrm{PGD}_{2}$ levels $\left(r_{s}=0.44, P=\right.$. 001 ). Adjustment for severity did not substantially improve these relationships. 


\section{Severe asthma is associated with increased CRTH2 receptor expression}

mRNA (Fig 4)-Although DP1 mRNA levels did not differ among groups (overall $P=$. 88), CRTH2 mRNA levels did differ (overall $P=.001$ ), being highest in SAs, significantly higher in SAs than in the Mild/no ICS group and HCs (each intergroup $P \leq .005$ ), and tending to be higher in SAs than in the Mild-Mod/ICS group (intergroup $P=.01$ ). Despite the lack of difference in DP1 expression, DP1 and CRTH2 mRNA levels correlated $\left(r_{s}=\right.$ $0.62, P<.0001$ for all subjects).

IHC/protein-The percentage of DP1 ${ }^{+}$cells did not differ among subject groups (overall $P$ $=.27$; Fig 5, $A$ and $B$; see Table E4). Double immunostaining of BAL cells identified $\mathrm{CRTH}_{2}{ }^{+}$cells (single positive, likely eosinophils), $\mathrm{CD}^{+}$lymphocytes, and $\mathrm{CRTH} 2^{+} \mathrm{CD} 3^{+}$ lymphocytes (double positive; Fig 5, D). The total percentage of CRTH2 ${ }^{+}$inflammatory cells (sum of CRTH2 ${ }^{+}$[single-positive] and $\mathrm{CRTH}_{2}{ }^{+} \mathrm{CD}^{+}$[double-positive] cells per total cells counted) was increased in SAs (overall $P=.0001$; Fig $5, C$ ). Total CRTH2 ${ }^{+}$cell percentages differentiated HCs from all asthmatic groups and SAs from the Mild-Mod/ICS group (each intergroup $P \leq .007$ ). The percentages of single- and double-positive CRTH2 cells were also higher in SAs (see Table E5 in this article's Online Repository at www.jacionline.org). The percentage of $\mathrm{CRTH} 2^{+}$cells correlated with $\mathrm{PGD}_{2}$ levels $\left(r_{s}=\right.$ $0.46, P=.001)$. There was no correlation between $\mathrm{CRTH} 2^{+}$cell numbers and mRNA levels.

\section{Clinical implications of $\mathrm{PGD}_{2}$ pathway markers in asthmatic patients}

Asthma exacerbations-In the previous 12 months, $96 \%$ of SAs, $27 \%$ of the Mild-Mod/ ICS group, and $9 \%$ of the Mild/no ICS group experienced an asthma exacerbation (overall $P$ $<.0001$, Table I). A historical exacerbation was associated with higher BAL fluid $\mathrm{PGD}_{2}$ levels, $\mathrm{HPGDS}^{+}$cell numbers, and $\mathrm{CRTH} 2^{+}$cell numbers and mRNA levels compared with those seen in asthmatic patients without such a history (all $P<.05$ ). Epithelial HPGDS mRNA and BAL cell DP1 levels did not differ between asthmatic patients with and without exacerbations (Table II).

Poor asthma control-Eleven asthmatic patients met the NAEPP criteria ${ }^{2}$ for wellcontrolled, 25 for not well-controlled, and 43 for very poorly controlled asthma. Although the majority of patients with very poorly controlled asthma had severe asthma, 6 patients with milder asthma were also in this category. Each control group had asthmatic patients from each severity group (see Table E6 in this article's Online Repository at www.jacionline.org). The majority of patients with very poorly controlled asthma met several criteria for poor control (70\% met $\geq 2$ criteria). BAL fluid $\mathrm{PGD}_{2}$ levels, $\mathrm{HPGDS}^{+}$cell numbers, and $\mathrm{CRTH}_{2}{ }^{+}$cell numbers and mRNA levels varied by level of control, with higher values in patients with very poorly controlled asthma (all $P<.04$, Table III). $\mathrm{PGD}_{2}$ and CRTH2 mRNA levels differentiated patients with well-controlled from those with very poorly controlled asthma (intergroup $P=.01$ and $P=.001$, respectively). HPGDS mRNA and BAL DP1 levels did not differ by level of control.

Association with $\mathbf{T}_{\mathbf{H}} \mathbf{2}$ inflammation-Peripheral blood eosinophilia ( $>300 / \mathrm{mL}$ ) and high $F_{\text {ENo levels ( }} 33 \mathrm{ppb}$, the median in these asthmatic patients), which were used as putative $\mathrm{T}_{\mathrm{H}} 2$ inflammation markers, ${ }^{24-26}$ were evaluated in relation to $\mathrm{PGD}_{2}$ pathway markers. Asthmatic patients with high blood eosinophil numbers had increased $\mathrm{PGD}_{2}$ levels, $\mathrm{HPGDS}^{+}$cell numbers and mRNA levels, and CRTH 2 mRNA levels (all $P \leq .035$ ). Those with high $\mathrm{F}_{\text {eno }}$ levels had increased $\mathrm{PGD}_{2}$ levels $(P=.02$, see Table E7 in this article's Online Repository at www.jacionline.org). Asthmatic patients with both high Feno levels and high peripheral eosinophil numbers compared with those with low levels of both had significantly increased $\mathrm{PGD}_{2}$ and CRTH2 mRNA levels $(P=.008$ and $P=.006$, 
respectively). These data support the association of $\mathrm{PGD}_{2}$ pathway activation with $\mathrm{T}_{\mathrm{H}} 2$ inflammatory markers, despite the use of ICSs and even OCSs.

\section{DISCUSSION}

This study identified a coordinated upregulation of the $\mathrm{PGD}_{2}$ pathway, from enzyme to product to receptor, particularly in patients with severe, poorly controlled, $\mathrm{T}_{\mathrm{H}}$ 2-associated asthma. Expanding on our previous study, BAL fluid $\mathrm{PGD}_{2}$ levels, measured by means of ELISA and confirmed by using the highly sensitive and specific LCMS, were highest in SAs. ${ }^{6}$ Levels of the likely enzymatic source of this $\mathrm{PGD}_{2}$, HPGDS, were also higher in the SA epithelium, correlated with its product $\left(\mathrm{PGD}_{2}\right)$, and strongly correlated with $\mathrm{MC}$ proteases, supporting an MC source. Although protein and mRNA levels for both $\mathrm{PGD}_{2}$ receptors were detectable in luminal inflammatory cells from all groups, neither $\mathrm{DP}^{+}$cells nor mRNA levels differed across groups. In contrast, BAL cell CRTH2 ${ }^{+}$cell numbers and mRNA levels were highest in SAs and markedly different from those seen in patients with milder asthma and HCs, with increases in both single-positive (likely eosinophils and perhaps basophils) and double-positive $\mathrm{CRTH} 2^{+} / \mathrm{CD}^{+}$cell numbers. Finally, upregulation of several elements of this pathway tracked with markers of $\mathrm{T}_{\mathrm{H}} 2$ inflammation, including both $\mathrm{F}_{\mathrm{ENO}}$ and blood eosinophils.

In addition to a differentiation of this pathway by using traditional severity definitions, this study was a novel evaluation of its relationship to an index of asthma control, which closely mirrors that suggested in asthma guidelines and which was able to distinguish patients with well-controlled, not well-controlled, and very poorly controlled asthma on the basis of symptoms, $\beta$-agonist use, and $\mathrm{FEV}_{1}$. When asthmatic patients were characterized into these groups, those with the worst control again had the greatest expression and activation of this pathway, with increases in epithelial HPGDS, BAL fluid $\mathrm{PGD}_{2}$, and luminal cell CRTH2 levels. Similarly, assessing future risk, asthmatic patients with an exacerbation in the prior 12 months had increased pathway activation compared with those without an exacerbation.

$\mathrm{PGD}_{2}$ generation requires phospholipases to generate arachidonic acid, COXs to convert arachidonic acid to $\mathrm{PGH}_{2}$, and prostaglandin $\mathrm{D}$ synthases to catalyze the isomerization of $\mathrm{PGH}_{2}$ to $\mathrm{PGD}_{2} \cdot{ }^{8-10}$ The involvement of multiple enzymes in $\mathrm{PGD}_{2}$ generation suggests that differences in any of these enzymes could contribute to differences in $\mathrm{BAL}$ fluid $\mathrm{PGD}_{2}$ levels. However, the correlation between $\mathrm{PGD}_{2}$ and HPGDS suggests that upregulation and activation of this enzyme plays a critical role. Unfortunately, human data on the regulation and activation of HPGDS, a glutathione-S-transferase, are limited. ${ }^{8,9}$ HPGDS expression and activity have been reported to be regulated by octomer-binding protein 1, although the transcription factors regulating human and murine HPGDS expression differ quite dramatically, suggesting species-specific regulation., ${ }^{9,27,28}$ Additionally, little is known about expressional control in MCs, and in fact, HPGDS might be constitutively expressed, suggesting a mere increase in MC numbers could increase HPGDS presence/activation., 910 Data from this study strongly suggest MCs are the source of HPGDS and ultimately $\mathrm{PGD}_{2}$ in asthmatic patients. Although the presence of MC HPGDS is well described in the nose and esophagus, ${ }^{11-13}$ this is the first study linking HPGDS to the MC in asthmatic patients. Interestingly, the weaker correlations of HPGDS and MCs in the HCs suggest that $\mathrm{PGD}_{2}$ might arise from other sources in these subjects, including macrophages. ${ }^{9,10}$ Finally, although a recent study reported HPGDS expression in eosinophils, very few immunostained HPGDS ${ }^{+}$cells appeared to be eosinophils. ${ }^{29}$

No matter the cell mix, the HPGDS product $\mathrm{PGD}_{2}$ was confirmed to be increased in BAL fluid in patients with severe and poorly controlled asthma. However, similar to the previous report, ${ }^{6} \mathrm{PGD}_{2}$ levels were low, raising questions about the specificity of these ELISA-based 
values. The ELISA levels were then validated in small numbers by using LCMS, correlating extremely well $\left(r_{s}=0.80, P=.006\right)$. Thus we are confident that they reflect actual values. Because $\mathrm{PGD}_{2}$ is rapidly converted to various metabolites, ${ }^{9,10}$ the strong relationship of the ELISA and LCMS $\mathrm{PGD}_{2}$ values, despite low levels, support the ongoing generation of the unstable parent compound, which is possibly indicative of chronic MC activation. ${ }^{10}$

The effects of $\mathrm{PGD}_{2}$ depend on which of the 3 receptors is activated and its location. ${ }^{9,10} \mathrm{TP}$, which is likely responsible for $\mathrm{PGD}_{2}$ 's acute bronchoconstricting effects, is found primarily on smooth muscle and platelets and thus not studied here. DP1, which is found on a variety of cells, including smooth muscle cells, goblet cells, dendritic cells, platelets, $\mathrm{T}_{\mathrm{H}} 2$ cells, and eosinophils, can be both anti-inflammatory and proinflammatory. ${ }^{9,10}$ DP1 activation causes vasodilation and bronchodilation, likely through cyclic AMP increases, whereas reports are conflicting on inflammation. ${ }^{9,10,14,15}$ Results of DP1 antagonist studies have been negative to date, ${ }^{30}$ which is consistent with our data showing that DP1 did not differentiate asthma severity, control, exacerbation, or $\mathrm{T}_{\mathrm{H}} 2$ inflammation.

Despite binding $\mathrm{PGD}_{2}$ with similar affinity to DP1, CRTH2 is not structurally related and signals through a different mechanism, inhibiting adenyl cyclase, reducing cyclic AMP, and increasing intracellular calcium levels, thereby activating chemotaxis, cell shape change, and $\mathrm{T}_{\mathrm{H}} 2$ cytokine expression. ${ }^{9,10}$ In human $\mathrm{T}_{\mathrm{H}} 2$ cells $\mathrm{PGD}_{2}$ induced $\mathrm{T}_{\mathrm{H}} 2$ cytokine production in a dose-dependent manner. ${ }^{31}$ A selective CRTH2, but not DP1, agonist mimicked PGD $_{2}$ 's effects, suggesting that $\mathrm{T}_{\mathrm{H}} 2$ activation is mediated by CRTH2 and not DP1. ${ }^{31}$ This is supported by our findings of positive relationships between both CRTH2 mRNA and IHC/ protein with BAL fluid $\mathrm{PGD}_{2}$ levels. Furthermore, BAL cell CRTH2 levels were strongly related to asthma severity, exacerbation, and control. Supporting these pathologic studies, a selective oral CRTH2 antagonist, OC000459, improved $\mathrm{FEV}_{1}$ and symptoms and decreased eosinophil numbers in patients with steroid-naive asthma. ${ }^{17}$ OC000459 also inhibited human $\mathrm{T}_{\mathrm{H}} 2$ cell chemotaxis, cytokine production, and eosinophil activation and blunted the late asthmatic response and sputum eosinophil increase after allergen challenge. ${ }^{18,32}$ Recently, the CRTH2 antagonist AMG 853 did not improve symptoms or lung function in patients with moderate-to-severe asthma receiving ICSs, ${ }^{33}$ suggesting that targeting a specific asthmatic phenotype is important for drug efficacy.

These in vitro and pharmacologic studies all support a strong relationship of $\mathrm{PGD}_{2}$ and CRTH2 to $\mathrm{T}_{\mathrm{H}} 2$ immune processes. Additionally, expression profiling studies related MCs to a $\mathrm{T}_{\mathrm{H}} 2$ immune process in patients with steroid-naive asthma. ${ }^{34}$ To determine whether a relationship persisted in patients with more severe asthma, we compared expression of our $\mathrm{PGD}_{2}$ pathway markers with both Feno levels and blood eosinophil numbers, which were reported to be surrogates of $\mathrm{T}_{\mathrm{H}} 2$ inflammation. ${ }^{24-26}$ Asthmatic patients with high blood eosinophil numbers had significantly higher $\mathrm{PGD}_{2}$, HPGDS, and CRTH2 expression than those with low eosinophil numbers. Furthermore, those with high Feno levels also had increased $\mathrm{PGD}_{2}$ levels. These relationships persisted despite corticosteroid use. Thus our data link the $\mathrm{PGD}_{2}$ pathway, in particular $\mathrm{PGD}_{2}$ and $\mathrm{CRTH} 2$, to a $\mathrm{T}_{\mathrm{H}} 2$ immune process, perhaps through direct effects of $\mathrm{PGD}_{2} / \mathrm{CRTH} 2$ to activate and maintain $\mathrm{T}_{\mathrm{H}} 2$ cells, as well as eosinophils.

This study is not without some limitations. Although SARP did not directly assess corticosteroid adherence, SAs had numerically higher levels of HPGDS, CRTH2, and $\mathrm{PGD}_{2}$ than any other group. Thus if subjects were simply not taking their corticosteroids, these levels should have been similar to those seen in the groups with milder asthma. The asthma control proxy used here obtained symptoms, activity, medication frequency, and even $\mathrm{FEV}_{1}$ data days if not weeks before the actual bronchoscopy, with the symptom and $\beta$-agonist scale used relying on a 3-month recall. Despite this, increases in $\mathrm{PGD}_{2}$ pathway elements 
were associated with historical worsening of asthma control and historical exacerbations, which is consistent with an association with an exacerbation-prone phenotype. Lastly, not every measurement was performed on every subject because of limited human samples, but the overall sample size for such a human-based study is still quite large.

In summary, this study presents evidence for an active $\mathrm{PGD}_{2}$ pathway, with increases in levels of the enzyme HPGDS in association with its product, $\mathrm{PGD}_{2}$, and one of its receptors, $\mathrm{CRTH} 2$, in a $\mathrm{T}_{\mathrm{H}} 2$ asthma phenotype, specifically in association with severe poorly controlled disease. The relationship of the $\mathrm{PGD}_{2}$-generating enzyme to the epithelial $\mathrm{MC}$ signature suggests that the source for this $\mathrm{PGD}_{2}$ is the $\mathrm{MC}$, whereas the increased symptoms could be due to activation, migration, or both of both eosinophils and $\mathrm{T}_{\mathrm{H}} 2$ lymphocytes. However, much remains to be understood regarding the factors regulating and activating this pathway in asthmatic patients. Studies targeting CRTH2 antagonists in patients with severe, poorly controlled asthma with evidence for $\mathrm{T}_{\mathrm{H}} 2$ pathway activation are needed to determine whether this pathway is critical to the maintenance or even augmentation of $\mathrm{T}_{\mathrm{H}} 2$ inflammation and the accompanying asthma.

\section{METHODS}

\section{Subjects, allergy testing, and spirometry}

Male and female subjects 18 to 65 years of age were recruited through SARP and the Electrophilic Fatty Acid Derivatives in Asthma study. Subjects were nonsmokers in the last year and had a 5 or less pack-year smoking history. Subjects completed clinical questionnaires, allergy testing, blood draw (including complete blood count with differential and IgE measurement), and Feno measurement, as previously described. ${ }^{\mathrm{E} 1, \mathrm{E} 2}$ Baseline and postbronchodilator spirometry was performed according to the ATS guidelines and the SARP protocol. ${ }^{\text {E1 }}$ Atopy was assessed by means of skin prick testing to 14 common aeroallergens. Subjects were considered atopic if there was 1 or more positive skin reaction (wheal larger than that elicited by the saline control). Serum IgE levels and complete blood counts with differentials were measured in the clinical laboratory of the University of Pittsburgh Medical Center.

\section{Questionnaires and classification of asthma control}

Information collected through questionnaires included general demographics, medical history, medication use, smoking history, and frequency of asthma symptoms and exacerbations. An asthma disease control measure was constructed to proxy for the 2007 NAEPP guidelines for those 12 years of age or older. ${ }^{\text {E3 }}$ Five domains were analyzed by using variables captured within the clinical and medication questionnaires and baseline spirometry. Asthma control was classified into 3 groups: well controlled, not well controlled, and very poorly controlled based on daytime symptom frequency (shortness of breath, wheezing, and chest tightness), nighttime awakenings, interference with normal activity, SABA use, and $\mathrm{FEV}_{1}$ percent predicted. Subjects rated symptoms, awakening, and SABA use frequency over the past 3 months on a 1- to 6-point scale: 1 , never; 2 , monthly; 3 , weekly but 2 or fewer times per week; 4 , more than 2 times per week but less than daily; 5 , daily; and 6, 2 or more times per day. Interference with normal activity over the past 2 weeks was determined by using the Juniper AQLQ activity limitation domain. ${ }^{\mathrm{E} 4}$ Consistent with NAEPP guidelines, subjects were assigned to the lowest asthma control group when 1 or more of the 5 criteria for that group was met. Well-controlled asthma was classified by using the following: symptoms 2 or fewer days per week (1,2, or 3 on frequency scale), nighttime awakenings 2 or fewer times per month ( 1 or 2 on frequency scale), no interference with normal activity (activity score on AQLQ of 7-5), use of SABAs 2 or fewer days per week $\left(1,2\right.$, or 3 on frequency scale), and $\mathrm{FEV}_{1}$ of greater than $80 \%$ of predicted 
value. Patients with not well-controlled asthma had symptoms more than 2 days per week (4 or 5 on the frequency scale), nighttime awakenings 1 to 3 times per week ( 3 or 4 on the frequency scale), some limitation of normal activity (activity score on AQLQ of $<5-3$ ), SABA use for symptom control on more than 2 days per week (4 or 5 on the frequency scale), and $\mathrm{FEV}_{1}$ of $60 \%$ to $80 \%$ of predicted value. Patients with very poorly controlled asthma reported symptoms throughout the day ( 6 on the frequency scale), nighttime awakenings 4 or more times per week ( 5 or 6 on the frequency scale), extreme limitation in normal activity (activity score on AQLQ of $<3-1$ ), SABA use several times per day ( 6 on the frequency scale), and $\mathrm{FEV}_{1}$ of less than $60 \%$ of predicted value.

\section{Bronchoscopy and sample processing}

During bronchoscopy, epithelial brushings from the proximal airways and BAL cells and fluid were obtained and processed according to previously published protocols and the SARP manual of procedures. ${ }^{\text {E2,E5 }}$ BAL cells and fluid were obtained and separated by means of centrifugation at $600 \mathrm{~g} .{ }^{\text {E1 }} \mathrm{BAL}$ fluid from the first $100 \mathrm{~mL}$ was placed in aliquots and stored at $-80^{\circ} \mathrm{C}$ for measurement of $\mathrm{PGD}_{2}$ levels. Cells were placed in Qiazol (Qiagen) for extraction of mRNA.

\section{BAL fluid $\mathrm{PGD}_{2}$ measurement}

ELISA-PGD 2 levels were measured by using an ELISA with commercially available components (Cayman Chemical Company) at ElisaTech, as previously described. ${ }^{\text {E2 }}$ Samples were first purified and concentrated with C18 Sep-Pak cartridges (Waters Corp, Milford, Mass) and then derivatized per the ELISA manufacturer's instructions. The assay's limit of detection was 2 to $5 \mathrm{pg} / \mathrm{mL}$.

LCMS-A subset of matched BAL fluid samples $(\mathrm{n}=10)$ was analyzed by using LCMS to validate the $\mathrm{PGD}_{2}$ measurements. $\mathrm{PGD}_{2}$ was purchased from Cayman Chemical Company. Water and acetonitrile were purchased from Honeywell Burdick \& Jackson (Morristown, $\mathrm{NJ})$. Four milliliters of BAL fluid was used for the liquid-liquid extraction of $\mathrm{PGD}_{2}$. Internal standard, $10 \mu \mathrm{L}$ of $50 \mathrm{ng} / \mathrm{mL}\left[{ }^{2} \mathrm{H}_{9}\right]-\mathrm{PGD}_{2}$, was added to each sample, followed by an equilibration time of 10 minutes. Next, $4 \mathrm{~mL}$ of ethyl acetatewas added, and the samples were shaken for 30 minutes and then centrifuged for 10 minutes at $2900 \mathrm{~g}$. The organic layer was removed, dried under nitrogen, and reconstituted in $100 \mu \mathrm{L}$ of methanol. An injection volume of $10 \mu \mathrm{L}$ was used for analysis with LCMS.

Analyses of $\mathrm{PGD}_{2}$ levels were conducted with a Shimadzu LC-20AD HPLC system (Columbia, Md) coupled to an AB-Sciex API-5000 triple-quadrupole mass spectrometer (Framingham, Mass). The liquid chromatography (LC) method used a Phenomenex Luna C18(2) column $(2.0 \mathrm{~mm} \mathrm{ID} \times 150 \mathrm{~mm}, 3 \mu \mathrm{m})$ by using water with $0.1 \%$ acetic acid as mobile phase A and acetonitrile with $0.1 \%$ acetic acid as mobile phase $\mathrm{B}$ at a flow rate of $200 \mu \mathrm{L} / \mathrm{min}$. The gradient increased from $10 \% \mathrm{~B}$ to $55 \% \mathrm{~B}$ in 45 minutes, followed by a 3minute wash step at $100 \% \mathrm{~B}$ and back to equilibration at $10 \% \mathrm{~B}$. The following mass spectrometer parameters were set: collision gas, 4 units; curtain gas, 40 units; ion source gas 1,40 units; ion source gas 2,40 units; ion spray voltage, $-4.2 \mathrm{kV}$; ionization temperature, $350^{\circ} \mathrm{C}$; decluster potential, $-55 \mathrm{~V}$; entrance potential, $-5 \mathrm{~V}$; collision energy, $-22 \mathrm{eV}$; and collision cell exit potential, $-18.4 \mathrm{~V}$. Single reaction monitoring (SRM) analyses were conducted in negative electro-spray ionization (ESI) mode. The following transitions were monitored for $\mathrm{PGD}_{2}: m / z 351.2\left(\mathrm{M}-\mathrm{H}^{+}\right) \rightarrow m / z 271.2\left(\mathrm{M}-\mathrm{H}^{+}-2 \mathrm{H}_{2} \mathrm{O}-\mathrm{CO}_{2}\right)$ and $m / z 360.2(\mathrm{M}-$ $\left.\mathrm{H}^{+}\right) \rightarrow m / z 280.2\left(\mathrm{M}-\mathrm{H}^{+}-2 \mathrm{H}_{2} \mathrm{O}-\mathrm{CO}_{2}\right)$ for $\left[{ }^{2} \mathrm{H}_{9}\right]-\mathrm{PGD}_{2}$.

$\mathrm{PGD}_{2}$ standard was used to prepare calibration solutions at different concentrations $(1,10$, $50,100,500,1000$, and $5000 \mathrm{pg}$ of each). The corresponding $\left[{ }^{2} \mathrm{H}_{9}\right]-\mathrm{PGD}_{2}$ internal standard 
was then added to the calibration solutions and experimental samples $(500 \mathrm{pg})$. Calibration solutions underwent the same sample preparation and analytic procedures as the experimental samples, as described above. Calibration curves were calculated with a linear regression analysis of the peak area ratios of standard versus the internal standard. Prostaglandin levels were calculated by means of interpolation from the calibration curve and reported in picograms per milliliter. The assay's limit of detection for PGD2 was $0.5 \mathrm{pg}$ / $\mathrm{mL}$.

\section{qRT-PCR}

Total RNA was extracted from epithelial cell brushings and BAL cells in Qiazol (Qiagen). Reverse transcription was performed with $1 \mu \mathrm{g}$ of total RNA and random hexamers in a 50$\mu \mathrm{L}$ reaction, according to the manufacturer's protocol (PE Applied Biosystems, Foster City, Calif). Epithelial brushing mRNA expression of HPGDS and the MC proteases tryptase and CPA3 was determined by using qRT-PCR, as previously described. ${ }^{\mathrm{E} 2}$ BAL cell mRNA expression for the $\mathrm{PGD}_{2}$ receptors DP1 and CRTH2/DP2 was also evaluated by means of qRT-PCR. The primers and probes were all purchased from Applied Biosystems (Assays on Demand: HPGDS, Hs00183950_m1; tryptase, Hs02576518_gH; CPA3, Hs00157019_m1; CRTH2, Hs01867513_s1; and DP1, Hs00830594_s1). The probes were labeled with the 5'reporter dye 6-carboxy fluorescein and the 3'-quencher dye 6-carboxy $\mathrm{N}, \mathrm{N}$,

N',N'tetramethylrhodamine. VIC-labeled ready-for-use human glyceraldehyde-3-phosphate dehydrogenase (GAPDH) probe and primers were also obtained from Applied Biosystems (GenBank accession no. NM-002046; part no. 4310884E). Real-time PCR was performed on the ABIPrism 7900 sequence detection system (Applied Biosystems) in the core facilities of the University of Pittsburgh. The mRNA levels for each of the markers were determined by indexing to GAPDH with the formula $1 / 2 \Delta \mathrm{Ct} \times 1000$. Analysis was performed on epithelial brushing samples if the GAPDH threshold was less than 27 cycles and BAL cell samples if the GAPDH threshold was less than 30.5 cycles.

\section{IHC}

All IHC was performed on cytospin preparations fixed in $2 \%$ to $4 \%$ paraformaldehyde.

\section{Epithelial brushing cytospin preparations for $\mathrm{PGD}_{\mathbf{2}}$ enzyme (HPGDS)-After} the appropriate blocking steps, cytospin preparations were incubated with rabbit polyclonal antihuman HPGDS antibody (Cayman Chemical Company) at 1:100 dilution overnight at $4^{\circ} \mathrm{C}$. Sections were rinsed, incubated with biotinylated secondary goat anti-rabbit antibody for 1 hour at room temperature, rinsed, and incubated in $\mathrm{ABC}$ reagent for 45 minutes (both from Vector Laboratories, Burlingame, Calif). Sections were developed with the chromogen 3-amino-9-ethylcarbazole (AEC) and then counterstained with hematoxylin. Slides were overlaid with Crystal Mount (Electron Microscopy Sciences, Hatfield, Pa). Slides were blinded, and numbers of HPGDS ${ }^{+}$cells were counted by 2 independent observers from a total of at least 500 cells in random fields at $\times 40$ magnification with the Nikon Eclipse TS100 (Mellville, NY). The percentage of $\mathrm{HPGDS}^{+}$cells was calculated by dividing the number of $\mathrm{HPGDS}^{+}$cells by the total number of cells counted. Control specimens were processed in the same manner, but the primary antibody was omitted.

BAL cell cytospin preparations for $\mathrm{PGD}_{2}$ receptors-After the appropriate blocking steps, cytospin preparations were incubated with rabbit polyclonal antibody against the DP1 receptor (Cayman Chemical Company) at 1:200 dilution overnight at $4^{\circ} \mathrm{C}$. Sections were rinsed, incubated with biotinylated secondary goat anti-rabbit antibody for 1 hour at room temperature, rinsed, and incubated in $\mathrm{ABC}$ reagent for 45 minutes (both from Vector Laboratories). Sections were rinsed again and developed with the chromogen AEC and then counterstained with hematoxylin. Slides were overlaid with Crystal Mount (Electron 
Microscopy Sciences). Slides were blinded, and the number of DP1 ${ }^{+}$cells was counted by 2 independent observers from a total of at least 500 cells in random fields at $\times 40$ magnification with the Nikon Eclipse TS100. The percentage of DP1 $1^{+}$cells was determined by dividing the number of $\mathrm{DP} 1^{+}$cells by the total number of inflammatory cells counted. Control specimens were processed in the same manner, but the primary antibody was omitted.

BAL cell cytospin preparations were double-labeled for CRTH2 and CD3 by using sequential immunostaining with anti-CRTH2 rat mAb (1:20, BM16, Santa Cruz Biotechnology) and anti-CD3 mouse mAb (1:200, Becton Dickinson, San Jose, Calif). After blocking, cytospin preparations were incubated with CRTH2 antibody, rinsed, incubated with biotinylated secondary rabbit anti-rat antibody followed by ABC reagent (both from Vector laboratories), and developed with AEC. After blocking with normal serum, rinsing, and treatment with the Avidin/Biotin blocking kit (Vector Laboratories), cytospin preparations were incubated with CD3 antibody and then biotinylated secondary horse antimouse antibody (Vector Laboratories) for 1 hour. Slides were treated with ABC-alkaline phosphatase complex and developed with alkaline phosphatase substrate solution as the chromogen (both from Vector Laboratories). Slides were blinded, and the number of cells positive for CRTH2, CD3, or both were counted by 2 independent observers from a total of at least 600 cells, as previously described. Cells were classified as $\mathrm{CD}^{+}$only (blue staining), $\mathrm{CRTH} 2^{+}$only (red), $\mathrm{CRTH} 2^{+} / \mathrm{CD}^{+}$double positive, or negative for either marker. Controls were performed, as previously described.

\section{Supplementary Material}

Refer to Web version on PubMed Central for supplementary material.

\section{Acknowledgments}

Supported by National Institute of Health/National Heart, Lung, and Blood Institute grants HL-69174, HL-109152-01, HL064937-10, NIH-F32 AI085633, and CTSI UL1 RR024153.

\section{Abbreviations used}

$\begin{array}{ll}\text { AEC } & \text { 3-Amino-9-ethylcarbazole } \\ \text { AQLQ } & \text { Asthma Quality of Life Questionnaire } \\ \text { ATS } & \text { American Thoracic Society } \\ \text { BAL } & \text { Bronchoalveolar lavage } \\ \text { CPA3 } & \text { Carboxypeptidase A3 } \\ \text { CRTH2/DP2 } & \text { Chemoattractant receptor-homologous molecule expressed on } \mathrm{T}_{\mathrm{H}^{2}} \\ \text { lymphocytes } \\ \text { FP1 } & \text { PGD }_{2} \text { receptor 1 } \\ \text { FNo } & \text { fraction of exhaled nitric oxide } \\ \text { GAPDH } & \text { Glyceraldehyde-3-phosphate dehydrogenase } \\ \text { HC } & \text { Healthy control subject } \\ \text { HPGDS } & \text { Hematopoietic prostaglandin D synthase } \\ \text { ICS } & \text { Inhaled corticosteroid } \\ \text { IHC } & \text { Immunohistochemistry }\end{array}$




$\begin{array}{ll}\text { LCMS } & \text { Liquid chromatography mass spectrometry } \\ \text { MC } & \text { Mast cell } \\ \text { NAEPP } & \text { National Asthma Education and Prevention Program } \\ \text { OCS } & \text { Oral corticosteroid } \\ \text { PGD } & \text { Prostaglandin } \mathrm{D}_{2} \\ \text { qRT-PCR } & \text { Quantitative real-time PCR } \\ \text { SA } & \text { Patient with severe asthma } \\ \text { SABA } & \text { Short-acting } \beta \text {-agonist } \\ \text { SARP } & \text { Severe Asthma Research Program } \\ \text { TP } & \text { Thromboxane receptor }\end{array}$

\section{REFERENCES}

1. American Thoracic Society. Proceedings of the ATS workshop on refractory asthma: current understanding, recommendations, and unanswered questions. Am J Respir Crit Care Med. 2000; 162:2341-51. [PubMed: 11112161]

2. National Asthma Education and Prevention Program. Guidelines for the diagnosis and management of asthma: expert panel report 3 (EPR3). National Institutes of Health/National Heart, Lung, and Blood Institute; Bethesda (MD): 2007. Publication no. 08-4051. Available at: http:// www.nhlbi.nih.gov/guidelines/asthma/asthgdln.pdf [Accessed January 16, 2012]

3. Moore WC, Bleecker ER, Curran-Everett D, Erzurum SC, Ameredes BT, Bacharier L, et al. National Heart, Lung, Blood Institute's Severe Asthma Research Program. Characterization of the severe asthma phenotype by the National Heart, Lung, and Blood Institute's Severe Asthma Research Program. J Allergy Clin Immunol. 2007; 119:405-13. [PubMed: 17291857]

4. Balzar S, Chu HW, Strand M, Wenzel S. Relationship of small airway chymase-positive mast cells and lung function in severe asthma. Am J Respir Crit Care Med. 2005; 171:431-9. [PubMed: 15563633]

5. Wenzel SE, Balzar S, Ampleford E, Hawkins GA, Busse WW, Calhoun WJ, et al. IL4R alpha mutations are associated with asthma exacerbations and mast cell/IgE expression. Am J Respir Crit Care Med. 2007; 175:570-6. [PubMed: 17170387]

6. Balzar S, Fajt ML, Comhair SA, Erzurum SC, Bleecker E, Busse WW, et al. Mast cell phenotype, location, and activation in severe asthma: data from the severe asthma research program. Am J Respir Crit Care Med. 2011; 183:299-309. [PubMed: 20813890]

7. Galli SJ, Nakae S, Tsai M. Mast cells in the development of adaptive immune responses. Nat Immunol. 2005; 6:135-42. [PubMed: 15662442]

8. Kanaoka Y, Fujimori K, Kikuno R, Sakaguchi Y, Urade Y, Hayaishi O. Structure and chromosomal localization of human and mouse genes for hematopoietic prostaglandin D synthase. Conservation of the ancestral genomic structure of sigma-class glutathione S-transferase. Eur J Biochem. 2000; 267:3315-22. [PubMed: 10824118]

9. Herlong JL, Scott TR. Positioning prostanoids of the D and J series in the immunopathogenic scheme. Immunol Lett. 2006; 102:121-31. [PubMed: 16310861]

10. Pettipher R, Hansel TT, Armer R. Antagonism of the prostaglandin D2 receptors DP1 and CRTH2 as an approach to treat allergic diseases. Nat Rev Drug Discov. 2007; 6:313-25. [PubMed: 17396136]

11. Nantel F, Fong C, Lamontagne S, Wright DH, Giaid A, Desrosiers M, et al. Expression of prostaglandin D synthase and the prostaglandin D2 receptors DP and CRTH2 in human nasal mucosa. Prostaglandins Other Lipid Mediat. 2004; 73:87-101. [PubMed: 15165034] 
12. Okano M, Fujiwara T, Sugata Y, Gotoh D, Masaoka Y, Sogo M, et al. Presence and characterization of prostaglandin D2-related molecules in nasal mucosa of patients with allergic rhinitis. Am J Rhinol. 2006; 20:342-8. [PubMed: 16871941]

13. Abonia JP, Blanchard C, Butz BB, Rainey HF, Collins MH, Stringer K, et al. Involvement of mast cells in eosinophilic esophagitis. JAllergy Clin Immunol. 2010; 126:140-9. [PubMed: 20538331]

14. Tanaka K, Hirai H, Takano S, Nakamura M, Nagata K. Effects of prostaglandin D2 on helper T cell functions. Biochem Biophys Res Commun. 2004; 316:1009-14. [PubMed: 15044085]

15. Gosset P, Pichavant M, Faveeuw C, Bureau F, Tonnel AB, Trottein F. Prostaglandin D2 affects the differentiation and functions of human dendritic cells: impact on the T cell response. Eur $\mathrm{J}$ Immunol. 2005; 35:1491-500. [PubMed: 15816013]

16. Stebbins KJ, Broadhead AR, Correa LD, Scott JM, Truong YP, Stearns BA, et al. Therapeutic efficacy of AM156, a novel prostanoid DP2 receptor antagonist, in murine models of allergic rhinitis and house dust mite-induced pulmonary inflammation. Eur J Pharmacol. 2010; 638:142-9. [PubMed: 20447387]

17. Barnes N, Pavord I, Chuchalin A, Bell J, Hunter M, Lewis T, et al. A randomized, double-blind, placebo-controlled study of the CRTH2 antagonist OC000459 in moderate persistent asthma. Clin Exp Allergy. 2012; 42:38-48. [PubMed: 21762224]

18. Singh D, Cadden P, Hunter M, Collins LP, Perkins M, Pettipher R, et al. Inhibition of the asthmatic allergen challenge response by the CRTH2 antagonist OC000459. Eur Respir J. 2012; 41:46-52. [PubMed: 22496329]

19. Fajt ML, Balzar S, Trudeau JB, Westcott JY, Wenzel SE. Elevated prostaglandin D2 (PGD2) levels in bronchoalveolar lavage fluid (BALF) in severe asthma. J Allergy Clin Immunol. 2010; 125:AB43.

20. Fajt ML, Balzar S, Trudeau JB, Hu H, Wenzel SE. Epithelial hematopoietic prostaglandin (PG) D synthase is increased in asthma. Am J Respir Crit Care Med. 2010; 181:A1440.

21. Fajt ML, Balzar S, Trudeau JB, Wenzel SE. CRTH2 receptor and its ligand, PGD2, are increased in severe asthma. Am J Respir Crit Care Med. 2011; 183:A4446.

22. Juniper EF, Guyatt GH, Epstein RS, Ferrie PJ, Jaeschke R, Hiller TK. Evaluation of impairment of health related quality of life in asthma: development of a questionnaire for use in clinical trials. Thorax. 1992; 47:76-83. [PubMed: 1549827]

23. Moore WC, Evans MD, Bleecker ER, Busse WW, Calhoun WJ, Castro M, et al. National Heart, Lung, and Blood Institute's Severe Asthma Research Program. Safety of investigative bronchoscopy in the Severe Asthma Research Program. J Allergy Clin Immunol. 2011; 128:32836.e3.

24. Chibana K, Trudeau JB, Mustovich AT, Hu H, Zhao J, Balzar S, et al. IL-13 induced increases in nitrite levels are primarily driven by increases in inducible nitric oxide synthase as compared with effects on arginases in human primary bronchial epithelial cells. Clin Exp Allergy. 2008; 38:93646. [PubMed: 18384429]

25. Corren J, Lemanske RF, Hanania NA, Korenblat PE, Parsey MV, Arron JR, et al. Lebrikizumab treatment in adults with asthma. N Engl J Med. 2011; 365:1088-98. [PubMed: 21812663]

26. Pavord ID, Korn S, Howarth P, Bleecker ER, Buhl R, Keene ON, et al. Mepolizumab for severe eosinophilic asthma (DREAM): a multicentre, double-blind, placebo-controlled trial. Lancet. 2012; 380:651-9. [PubMed: 22901886]

27. Mahmud I, Ueda N, Yamaguchi H, Yamashita R, Yamamoto S, Kanaoka Y, et al. Prostaglandin D synthase in human megakaryoblastic cells. J Biol Chem. 1997; 272:28263-6. [PubMed: 9353279]

28. Fujimori K, Kanaoka Y, Sakaguchi Y, Urade Y. Transcriptional activation of the human hematopoietic prostaglandin D synthase gene in megakaryoblastic cells. Roles of the oct-1 element in the 5'-flanking region and the AP-2 element in the untranslated exon 1. J Biol Chem. 2000; 275:40511-6. [PubMed: 10998423]

29. Luna-Gomes T, Magalhães KG, Mesquita-Santos FP, Bakker-Abreu I, Samico RF, Molinaro R, et al. Eosinophils as a novel cell source of prostaglandin D2: autocrine role in allergic inflammation. J Immunol. 2011; 187:6518-26. [PubMed: 22102725] 
30. Philip G, van Adelsberg J, Loeys T, Liu N, Wong P, Lai E, et al. Clinical studies of the DP1 antagonist laropiprant in asthma and allergic rhinitis. J Allergy Clin Immunol. 2009; 124:942-8. [PubMed: 19748656]

31. Xue L, Gyles SL, Wettey FR, Gazi L, Townsend E, Hunter MG, et al. Prostaglandin D2 causes preferential induction of proinflammatory Th2 cytokine production through an action on chemoattractant receptor-like molecule expressed on Th2 cells. J Immunol. 2005; 175:6531-6. [PubMed: 16272307]

32. Pettipher R, Vinall SL, Xue L, Speight G, Townsend ER, Gazi L, et al. Pharmacologic profile of OC000459, a potent, selective, and orally active D prostanoid receptor 2 antagonist that inhibits mast cell-dependent activation of T helper 2 lymphocytes and eosinophils. J Pharmacol Exp Ther. 2012; 340:473-82. [PubMed: 22106101]

33. Busse WW, Wenzel SE, Meltzer EO, Kerwin EM, Liu MC, Zhang N, et al. Safety and efficacy of the prostaglandin $\mathrm{D}(2)$ receptor antagonist AMG 853 in asthmatic patients. J Allergy Clin Immunol. 2013; 131:339-45. [PubMed: 23174659]

34. Dougherty RH, Sidhu SS, Raman K, Solon M, Solberg OD, Caughey GH, et al. Accumulation of intraepithelial mast cells with a unique protease phenotype in $\mathrm{T}(\mathrm{H}) 2$-high asthma. J Allergy Clin Immunol. 2010; 125:1046-53. [PubMed: 20451039]

E1. Moore WC, Bleecker ER, Curran-Everett D, Erzurum SC, Ameredes BT, Bacharier L, et al. National Heart, Lung, Blood Institute's Severe Asthma Research Program. Characterization of the severe asthma phenotype by the National Heart, Lung, and Blood Institute's Severe Asthma Research Program. J Allergy Clin Immunol. 2007; 119:405-13. [PubMed: 17291857]

E2. Balzar S, Fajt ML, Comhair SA, Erzurum SC, Bleecker E, Busse WW, et al. Mast cell phenotype, location, and activation in severe asthma: data from the severe asthma research program. Am J Respir Crit Care Med. 2011; 183:299-309. [PubMed: 20813890]

E3. National Asthma Education and Prevention Program. Guidelines for the diagnosis and management of asthma: expert panel report 3 (EPR3). National Institutes of Health/National Heart, Lung, and Blood Institute; Bethesda (MD): 2007. Publication no. 08-4051. Available at: http://www.nhlbi.nih.gov/guidelines/asthma/asthgdln.pdf [Accessed January 16, 2012]

E4. Juniper EF, Guyatt GH, Epstein RS, Ferrie PJ, Jaeschke R, Hiller TK. Evaluation of impairment of health related quality of life in asthma: development of a questionnaire for use in clinical trials. Thorax. 1992; 47:76-83. [PubMed: 1549827]

E5. Moore WC, Evans MD, Bleecker ER, Busse WW, Calhoun WJ, Castro M, et al. National Heart, Lung, and Blood Institute's Severe Asthma Research Program. Safety of investigative bronchoscopy in the Severe Asthma Research Program. J Allergy Clin Immunol. 2011; 128:32836.e3. [PubMed: 21496892] 


\section{Key messages}

- Levels of several elements of the $\mathrm{PGD}_{2}$ pathway, including the enzyme HPGDS, the CRTH2 receptor, and the end product $\mathrm{PGD}_{2}$ are increased in patients with severe, poorly controlled asthma.

- These pathway elements associate with markers of $\mathrm{T}_{\mathrm{H}} 2$ inflammation and exacerbations.

- The $\mathrm{PGD}_{2}$ pathway could be a potential new therapeutic target in patients with severe, poorly controlled, $\mathrm{T}_{\mathrm{H}}$ 2-high asthma unresponsive to standard therapies. 


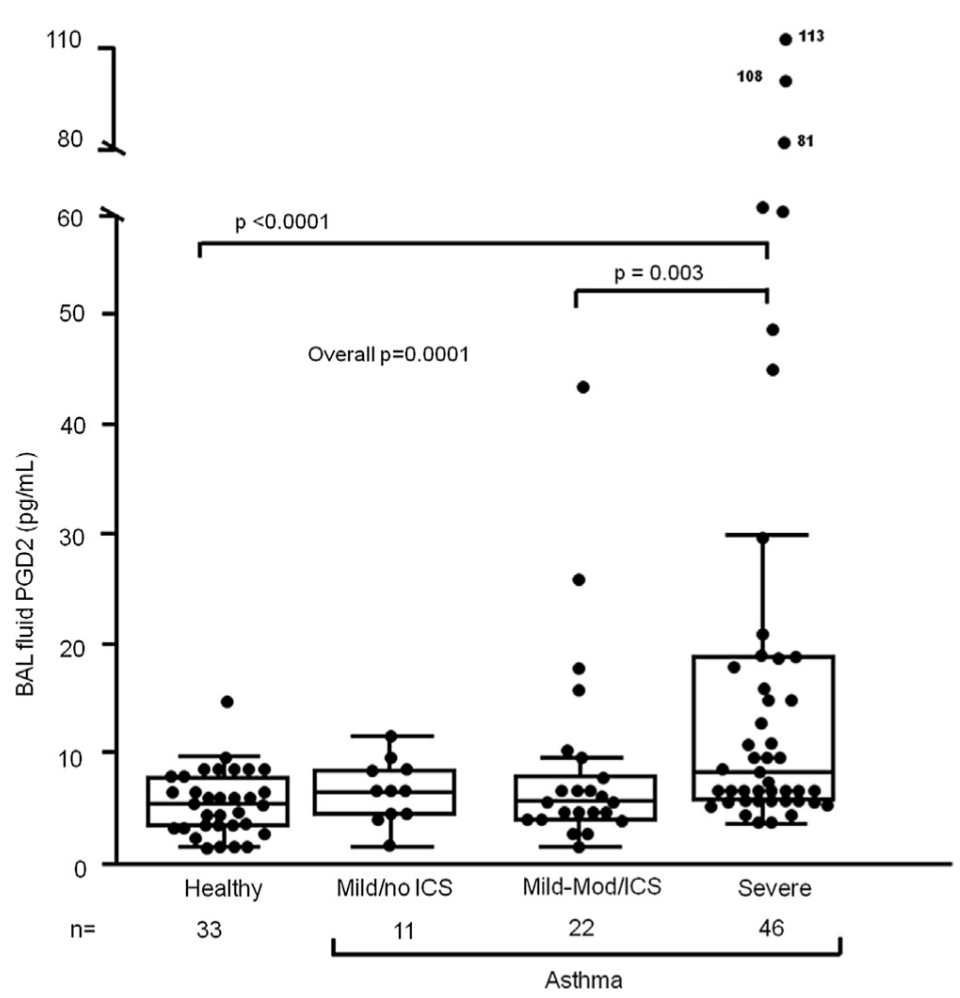

FIG 1.

$\mathrm{PGD}_{2}$ levels measured by using ELISA in BAL fluid samples. 

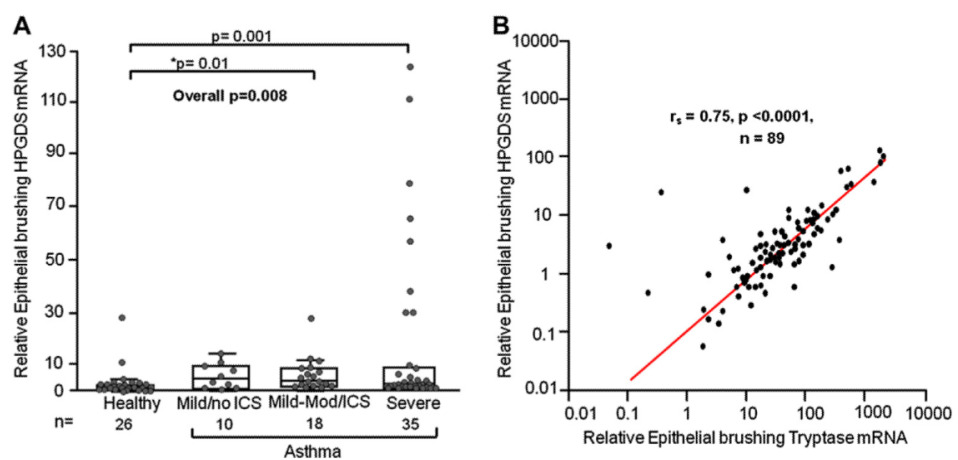

FIG 2.

A, qRT-PCR of HPGDS mRNA transcripts in epithelial cell brushings relative to glyceraldehyde-3-phosphate dehydrogenase (GAPDH). *The difference between HCs and the Mild-Mod/ICS group tended to be different $(P=.01)$ but did not reach significance. B, Correlation between HPGDS and tryptase epithelial cell brushing mRNA levels. 
A

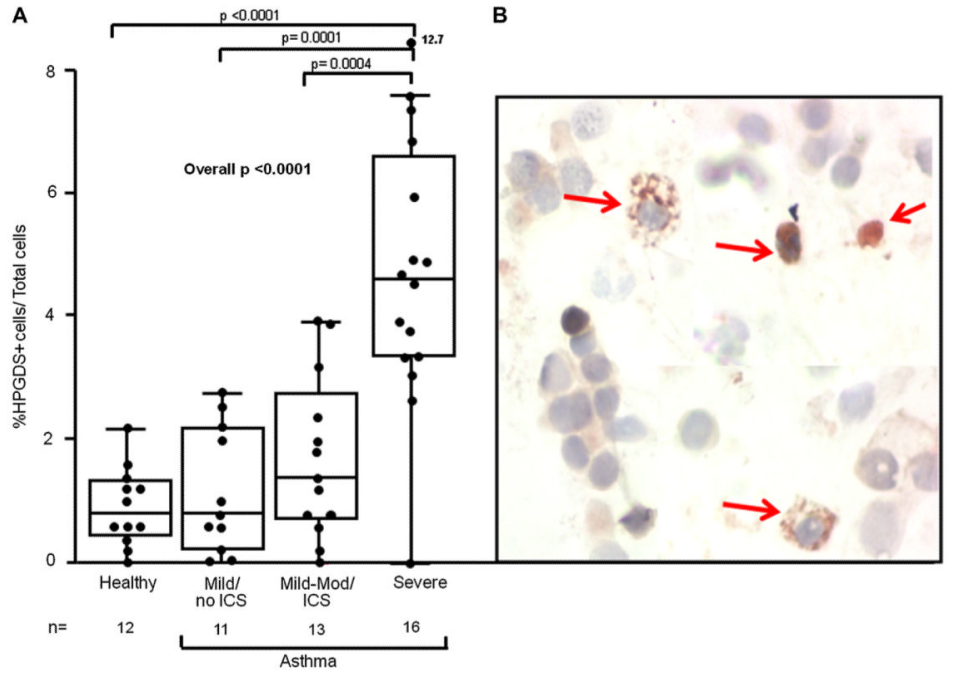

FIG 3.

Epithelial brushing cell cytospin preparations. A, Comparison of the percentage of total HPGDS $^{+}$cells, as determined by means of IHC. B, Cytospin preparations (fixed in paraformaldehyde) stained with HPGDS antibody. Red arrows, HPGDS ${ }^{+}$cells from an SA. Panels are shown at $\times 40$ magnification. 


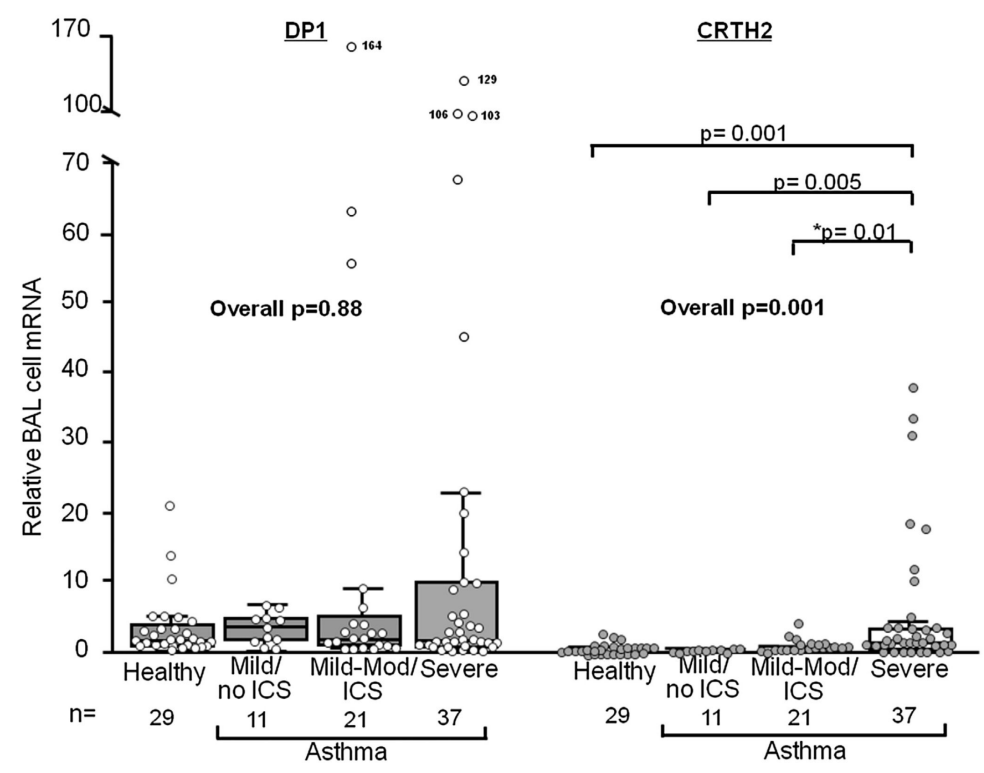

FIG 4.

qRT-PCR of DP1 and CRTH2 mRNA transcripts in BAL cells relative to glyceraldehyde-3phosphate dehydrogenase (GAPDH). *The difference between the Mild-Mod/ICS group versus $\mathrm{SAs}$ tended to be different $(P=.01)$ but did not reach significance. 

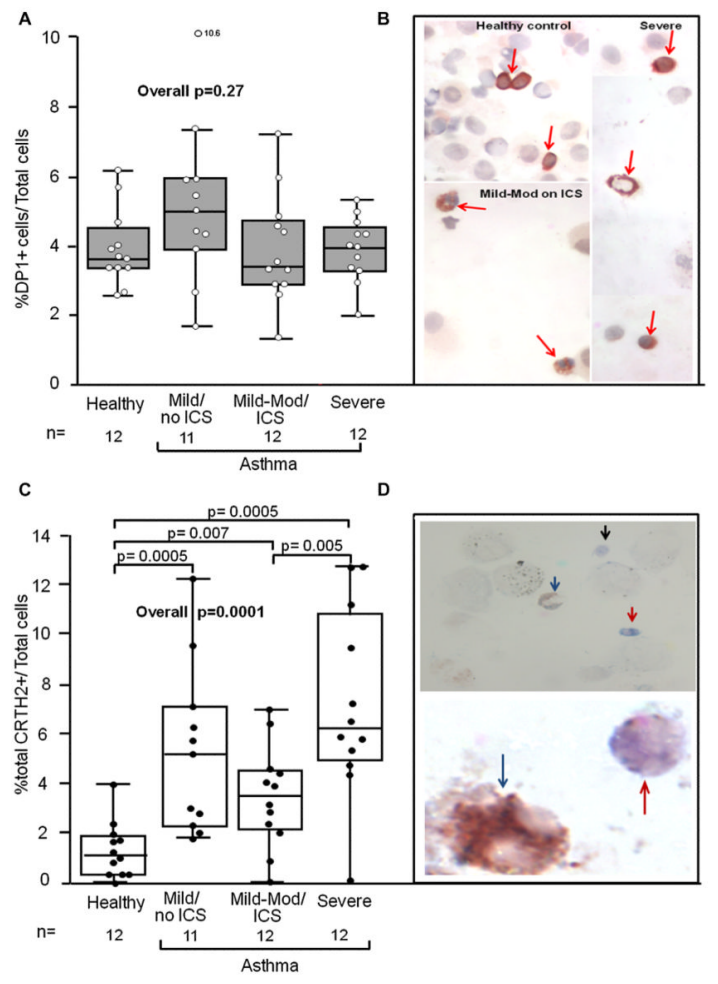

FIG 5.

BAL cell cytospin preparations. A and $\mathbf{C}$, Comparison of the percentage of total BAL cells positive for DP1 (Fig 5, A) and CRTH2 (Fig 5, C), as determined by means of IHC, is shown. B, Cytospin preparations stained with DP1 antibody. Red arrows, DP1 ${ }^{+}$cells. Upper left panel, HC; lower left panel, Mild-Mod/ICS subject; right panel, SA. Panels are shown at $\times 40$ magnification. D, Cytospin preparations from an SA double stained with CRTH2 and CD3 antibodies. The upper panel is shown at $\times 40$ magnification. The lower panel is shown at $\times 100$ magnification. Red arrow, $\mathrm{CRTH} 2^{+} / \mathrm{CD}^{+}$lymphocyte; blue arrow, $\mathrm{CRTH} 2^{+}$ eosinophil; black arrow, $\mathrm{CD}^{+}$lymphocyte. 
TABLE I

Baseline demographic characteristics $(\mathrm{n}=112)$

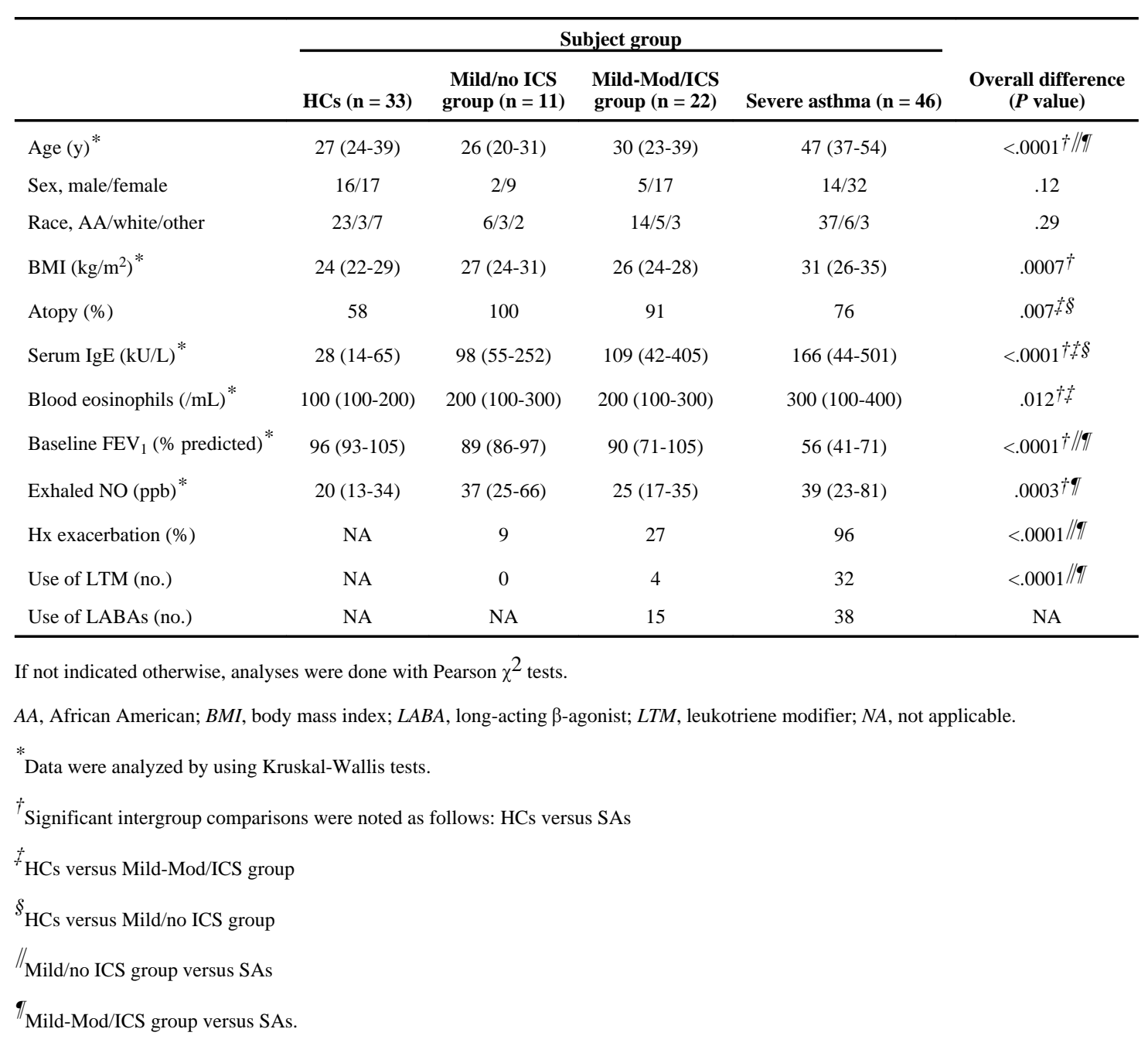


TABLE II

History of recent exacerbation and $\mathrm{PGD}_{2}$ pathway markers in all asthmatic patients

\begin{tabular}{|c|c|c|c|c|c|}
\hline \multirow[b]{3}{*}{$\mathrm{PGD}_{2}$ pathway marker } & \multicolumn{4}{|c|}{ Recent asthma exacerbation: } & \multirow{3}{*}{$\begin{array}{l}p \\
\text { value }\end{array}$} \\
\hline & \multicolumn{2}{|l|}{ No } & \multicolumn{2}{|l|}{$\underline{\text { Yes }}$} & \\
\hline & No. & Median (IQR) & No. & Median (IQR) & \\
\hline BAL fluid $\mathrm{PGD}_{2}(\mathrm{pg} / \mathrm{mL})$ & 28 & $6.0(4.6-8.8)$ & 51 & $8.5(6.0-19)$ & .001 \\
\hline Epithelial HPGDS mRNA & 24 & $5.0(1.2-8.7)$ & 39 & $3.3(1.8-9.5)$ & .99 \\
\hline $\begin{array}{r}\mathrm{HPGDS}^{+} \text {cells in } \\
\text { epithelium (\%) }\end{array}$ & 21 & $1.0(0.6-2.3)$ & 19 & $4.0(2.7-6.0)$ & .0002 \\
\hline BAL cell CRTH2 mRNA & 26 & $0.1(0.04-0.2)$ & 43 & $0.2(0.1-1.7)$ & .015 \\
\hline $\mathrm{CRTH}^{+}{ }^{+}$BAL cells $(\%)$ & 19 & $3.9(2.1-6.3)$ & 16 & $5.9(4.4-9.0)$ & .048 \\
\hline BAL cell DP1 mRNA & 26 & $2.1(1.1-6.3)$ & 43 & $1.4(0.5-9.1)$ & .60 \\
\hline $\mathrm{DP}^{+}{ }^{+} \mathrm{BAL}$ cells $(\%)$ & 19 & $4.4(3.3-5.9)$ & 16 & $4.0(3.0-4.5)$ & .21 \\
\hline
\end{tabular}

$I Q R$, Interquartile range. 


\section{TABLE III}

Level of NAEPP asthma control and $\mathrm{PGD}_{2}$ pathway markers in all asthmatic patients

\begin{tabular}{|c|c|c|c|c|c|c|c|}
\hline \multirow[b]{3}{*}{$\mathbf{P G D}_{2}$ pathway marker } & \multicolumn{7}{|c|}{ Level of asthma control } \\
\hline & \multicolumn{2}{|r|}{ Well controlled } & \multicolumn{2}{|c|}{ Not well controlled } & \multicolumn{2}{|c|}{ Very poorly controlled } & \multirow[b]{2}{*}{ Overall $P$ value } \\
\hline & No. & Median (IQR) & No. & Median (IQR) & No. & Median (IQR & \\
\hline BAL fluid $\mathrm{PGD}_{2}(\mathrm{pg} / \mathrm{mL})$ & 11 & $6.5(4.1-7.0)$ & 25 & $7.0(5.0-10.5)$ & 43 & $9.0(6.0-19.0)$ & $.014^{*}$ \\
\hline Epithelial HPGDS mRNA & 10 & $6.2(0.9-17.6)$ & 21 & $4.4(2.5-8.0)$ & 32 & $3.0(1.7-8.1)$ & .84 \\
\hline $\begin{array}{l}\text { HPGDS }^{+} \text {cells in } \\
\text { epithelium (\%) }\end{array}$ & 7 & $1.4(0.6-2.2)$ & 16 & $2.0(0.1-3.1)$ & 17 & $3.8(1.8-4.8)$ & .038 \\
\hline BAL cell CRTH2 mRNA & 10 & $0.03(0.008-0.1)$ & 25 & $0.15(0.06-0.8)$ & 34 & $0.2(0.1-1.8)$ & $.004^{*}$ \\
\hline CRTH $2+$ BAL cells ( $\%)$ & 6 & $4.7(3.0-5.9)$ & 14 & $2.5(1.6-6.5)$ & 15 & $5.9(4.3-9.5)$ & .041 \\
\hline BAL cell DP1 mRNA & 10 & $0.7(0.2-2.2)$ & 25 & $3.6(1.0-5.7)$ & 34 & $1.8(0.7-9.2)$ & .11 \\
\hline $\mathrm{DP} 1^{+}$BAL cells $(\%)$ & 6 & $3.6(2.7-5.4)$ & 14 & $4.6(3.3-5.9)$ & 15 & $3.9(3.3-4.6)$ & .35 \\
\hline
\end{tabular}

$I Q R$, Interquartile range.

* Significant intergroup comparisons were found between patients with well-controlled asthma and very those with poorly controlled asthma. The asthma control proxy was based on 2007 NAEPP guidelines. 